This item was submitted to Loughborough's Research Repository by the author.

Items in Figshare are protected by copyright, with all rights reserved, unless otherwise indicated.

\title{
The impact of reading for pleasure on blind and partially sighted adults and
} its implications for materials provision

PLEASE CITE THE PUBLISHED VERSION

http://dx.doi.org/10.1177/0961000613488409

PUBLISHER

SAGE Publications (C) The Author(s)

VERSION

AM (Accepted Manuscript)

LICENCE

CC BY-NC-ND 4.0

\section{REPOSITORY RECORD}

Spacey, Rachel E., Claire Creaser, and Debbie Hicks. 2019. "The Impact of Reading for Pleasure on Blind and Partially Sighted Adults and Its Implications for Materials Provision”. figshare.

https://hdl.handle.net/2134/13380. 
This item was submitted to Loughborough's Institutional Repository (https://dspace.lboro.ac.uk/) by the author and is made available under the following Creative Commons Licence conditions.

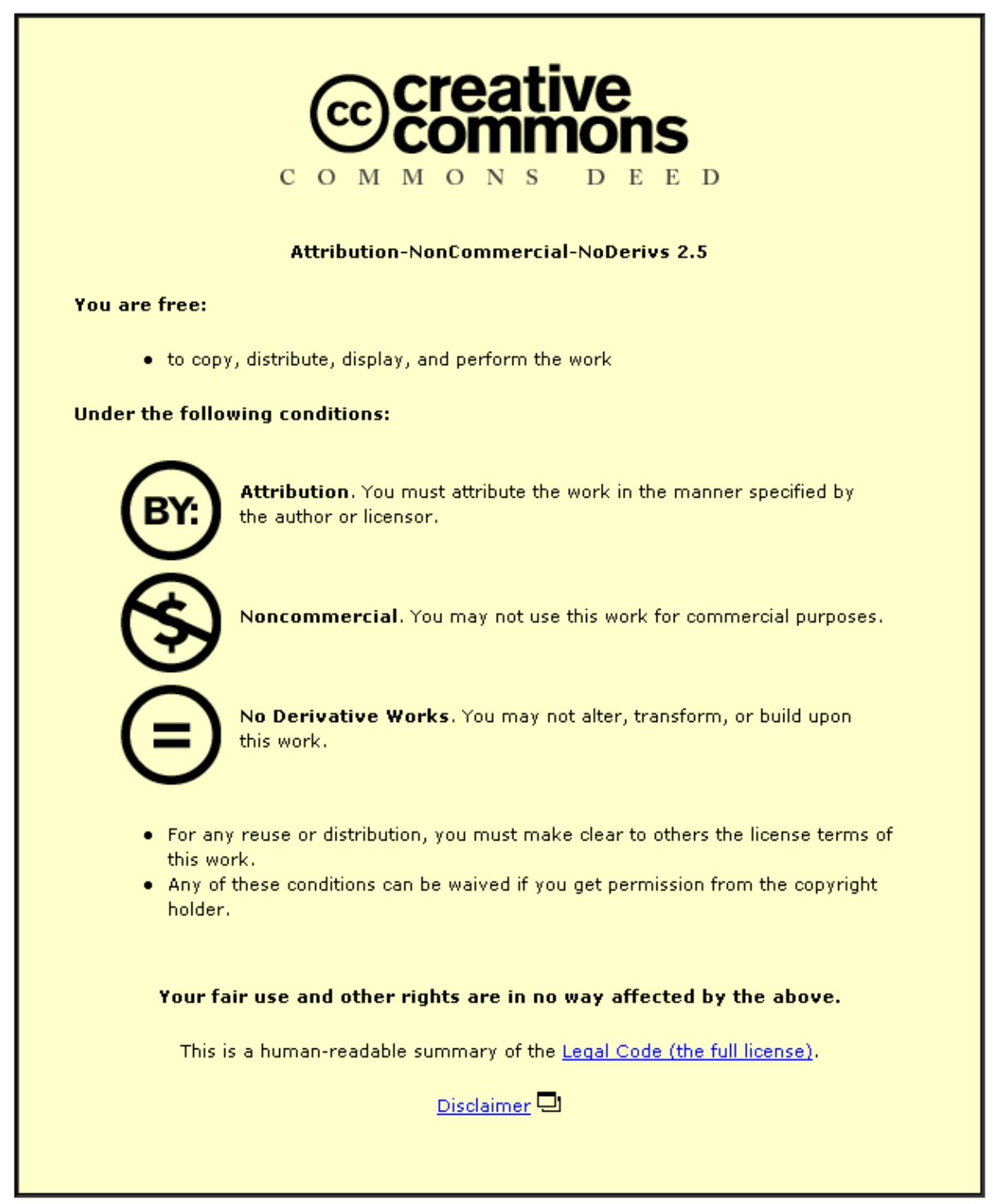

For the full text of this licence, please go to: http://creativecommons.org/licenses/by-nc-nd/2.5/ 
The impact of reading for pleasure on blind and partially sighted adults and its implications for materials provision

\section{Abstract}

This article reports the findings of research commissioned by the Royal National Institute of Blind People (RNIB) to explore the impacts of reading for pleasure on blind and partially sighted adults. Data were collected via interviews, an online survey and six case studies. The results reveal that for 82 per cent of participants reading for pleasure was 'very important' especially to relax and 59 per cent of participants read for more than 10 hours a week. Eighty-five per cent of participants used multiple reading formats including traditional hard copy and digital formats. The implications for materials provision and presentation for libraries and charitable organisations are considered in light of the findings.

Key words

Visually impaired, blind, partially sighted, reading, public libraries, reading groups 


\section{Introduction}

In 2012, the Royal National Institute of Blind People (RNIB) commissioned LISU at Loughborough University and The Reading Agency to undertake research with blind and partially sighted adults to explore the impact of reading for

pleasure (1). As well as highlighting the importance and value of reading for pleasure (2) and the ways in which adults read, this research also drew attention to the difficulties blind and partially sighted adults must contend with in order to obtain reading materials in appropriate accessible formats. The objectives of this paper are to consider some of the pertinent findings of the research and explore some of the implications for those providing reading materials to blind and partially sighted adults, including public libraries and charitable organisations. This article begins with contextual background detailing the availability and popularity of reading formats available to blind and partially sighted adults. This is followed by an outline of the research methods used including interviews, an online survey of blind and partially sighted adult readers and six case studies (3). The key findings from the research are summarised in the Findings section and they are reflected upon in the Discussion section. The significance of the research findings for organisations providing reading for pleasure materials are summarised and some recommendations for practice are offered. 


\section{Background}

'Partial sight and blindness can be broadly defined as a limitation in one or more functions of the eye or visual system, most commonly impairment of visual acuity (sharpness or clarity of vision), visual fields (the ability to detect objects to either side or above or below the direction in which the person is looking), contrast sensitivity and colour vision' (Access Economics, 2009:2). In the UK, it is estimated that there are almost two million blind and partially sighted people, which equates to approximately one person in thirty (RNIB, 2012). 'About 18 per cent of blind people are totally blind - most can distinguish between light and dark' (Reading Sight, 2013:para.4). Although sight loss affects people of all ages, adults are more likely to experience sight loss as they age; '90\% are over the age of 65' (Beech, 2007:6). With an ageing population, it is predicted that by 2050 , the number of people in the UK with sight loss will double to almost four million (RNIB, 2012).

Public library services in addition to the loan of accessible reading materials (which are defined here as providing the blind or partially sighted reader with an equivalent experience to reading the printed original), provide a wide range of services and support to blind and partially sighted readers (Kinnell et al., 2000). Public libraries tend to provide hard copy reading materials including large print books, audiobooks on cassette, CD and PlayAways ${ }^{\mathrm{TM}}$ which are all-in-one 
players with pre-loaded digital audio. They may also offer reading groups specifically for blind and partially sighted adults. In 2008, 42 English and Welsh public library authorities had links to reading groups for blind and partially sighted adults and 134 groups were identified across England and Wales (The Reading Agency, 2008).

At a time of local authority financial retrenchment there has been pressure on public library service stock budgets (4), staffing and public library services in general (5) which may impact negatively on blind and partially sighted adults. RNIB wished to establish the kinds of impacts reading has on the lives on adults with visual impairment in order to inform campaigns in relation to budget cuts. Whilst there has been much research exploring the effect of reading on sighted adults and children (6) there has been little with blind and partially sighted adults. The research for RNIB aimed to address this gap.

\section{Accessible formats}

Adults who are blind or partially sighted read in a number of ways using traditional hard copy and digital formats. Traditional hard copy formats include braille and Moon - both ways of reading by touch - and large print and giant print books (generally regarded as 16 point and 24 point font size respectively). In the UK, books in braille and giant print can be borrowed by post from the RNIB National Library Service (NLS), which was formed by RNIB and the 
National Library for the Blind in 2007 . The postal service is free for blind and partially sighted adults and organisations working with them, using the Royal Mail's Articles for the Blind Scheme.

Since 1935, listening has been an important way for people who develop visual impairment to read, often in later life, because they do not learn braille (Hyder, 2008b). Audiobooks, often known as talking books or spoken word, are unabridged books recorded by a human voice onto cassette, CD or MP3formatted CD (MP3CD). They are also available in digital formats to download including MP3. Downloadable audiobooks (DABs) can be transferred onto a PC, MP3 player, tablet or mobile phone. In the UK, DABs are available commercially from a variety of suppliers including for example Audible, part of the Amazon group, and AudioGO, formerly BBC Audiobooks, as well as from charitable organisations such as Calibre Audio Library and Listening Books.

Some texts are available as abridged readings, or dramatisations. In the UK, RNIB do not consider these to be an accessible format, as they do not provide the blind or partially sighted reader with an equivalent experience to reading the printed original.

The technology available to blind and partially sighted readers to help them access books has changed. The RNIB Talking Books service was originally 
based on 8-track cassettes; these have been replaced by the DAISY (Digital Accessible Information SYstem) format, developed in the 1990s. DAISY is a technical standard for audiobooks based on MP3 and XML. A DAISY book offers the reader an audiobook with advanced features including navigation of the text. They can be listened to on dedicated DAISY players, PCs using DAISY playback software, mobile phones and MP3 players.

Electronic book (eBook) readers offer blind and partially sighted readers a range of options, and the accessibility of such devices is growing rapidly. Depending on the device, and the functionality in the book itself, a reader can enlarge the font size of the display screen, listen to synthetic audio, when 'textto-speech' is enabled, or connect a refreshable electronic braille display. Textto-speech can also be used on PCs and other devices, to read out text in computer-generated synthetic speech. EBooks and eReaders may present blind and partially sighted readers with problems, however, if content cannot be downloaded or the device used without sighted assistance (Creaser, 2012). In relation to usage figures of the different reading formats, a study based on approximately 1,000 interviews with blind and partially sighted adults found that less than half read ordinary print, 57 per cent read large print, five per cent read braille and 71 per cent used magnifiers for reading (Douglas et al., 2006). An earlier study of blind and partially sighted users of library and information 
services, based on over 500 interviews, found that over 80 per cent of interviewees used audiobooks (Davies et al., 2001). Both studies pre-dated the widespread availability of eBooks.

\section{Methods}

A mixed-methods approach was used in this study including interviews, a survey and case studies. Following a review of the relevant literature on the impact of reading for pleasure on both the sighted and blind and partially sighted populations, an interview schedule was developed which was circulated amongst the RNIB Steering Group for comments and suggestions until a final version was agreed upon. The Group provided advice on reading formats and on the types and degrees of sight loss. Structured interviews with 108 blind and partially sighted readers in the UK were undertaken between May and July 2012. Eighty-eight of the interviews were undertaken on the telephone (see Appendix 1 for interview/survey questions) and 20 were completed in person during visits to reading groups. All the interviews were recorded digitally and transcribed. The interview questions were also formatted as a questionnaire survey which was hosted online by Bristol Online Surveys (BOS) during June 2012, and completed by 186 adults in the UK (see Appendix 1). The survey was used to gather additional data, and to broaden the potential demographic 
coverage of the research. The questionnaire was almost identical to the interview schedule with the exception that whilst the interviews were standardised open-ended interviews both face-to-face and on the telephone, the online survey had predetermined category responses derived from the literature review, for ease of completion. BOS' suggestions for making the survey accessible to visually impaired users were consulted and the draft survey was also tested by members of the RNIB steering group. Six case studies were also prepared, with volunteers from the interviews and online survey. The case studies included an additional, longer interview with the reader, exploring specific issues in depth.

A total of 294 blind and partially sighted readers participated in the research. Willing participants were recruited via publicity materials circulated by RNIB amongst their networks supporting blind and partially sighted adults and their electronic publications and communications. The project was also promoted by The Reading Agency including their Reading Groups for Everyone website (7) which lists details of reading groups by geographical area including groups for visually impaired readers, and Share the Vision (8) membership organisations which include Calibre Audio Library. This was a self-selecting rather than a random sample of blind and partially sighted adult readers since many of the interviewees heard about the call for volunteers via resources and groups for 
blind and partially sighted readers and therefore it may be assumed that they were enthusiastic readers. Neither were participants sampled selectively. Rather, the researcher endeavoured to interview all those who made contact with the project team by email and telephone on a first-come, first-served basis in order to complete the gathering of data within the allocated time. On analysing the data, it became apparent that there were differences in the response patterns between interviewees and survey respondents when answering the same questions. Survey respondents tended to tick more boxes than interviewees in questions allowing multiple responses, and were less likely to add remarks which did not fit the pre-coded options. This was taken into account in the analysis, and indication given where it may affect the interpretation of the figures. Full details of the methodology are available in the full report of the study (1).

\section{Findings}

The characteristics of the participants in this study including location, age (9) and gender are reported in Table 1 below.

Survey Interview Total \% of total

a) Location

England

145

96

241

$83 \%$ 


\begin{tabular}{lrrrr} 
Wales & 9 & 4 & 13 & $4 \%$ \\
Scotland & 21 & 8 & 29 & $10 \%$ \\
N Ireland & 6 & 0 & 6 & $2 \%$ \\
\hline Total & 181 & 108 & 289 & \\
\hline b) Age & & & & \\
\hline $20-34$ & 8 & 6 & 14 & $5 \%$ \\
$35-49$ & 29 & 11 & 40 & $14 \%$ \\
$50-64$ & 82 & 23 & 105 & $37 \%$ \\
$65-79$ & 43 & 40 & 83 & $29 \%$ \\
$80+$ & 16 & 28 & 44 & $15 \%$ \\
\hline Total & 178 & 108 & 286 & \\
\hline c) Gender & & & & \\
\hline Male & 82 & 40 & 122 & $43 \%$ \\
Female & 96 & 68 & 164 & $57 \%$ \\
\hline Total & 178 & 108 & 286 & \\
\hline
\end{tabular}

In relation to sight, respondents were asked to select the statement that best described what they could see from a list of seven options (Table 2). 
a) Which of the following best describes what you can see?

\begin{tabular}{lrrrr}
\hline $\begin{array}{l}\text { Prefer not to answer } \\
\text { No light perception }\end{array}$ & 13 & 0 & 13 & $5 \%$ \\
$\begin{array}{l}\text { In a room during daytime, you can tell by the } \\
\quad \text { light where the windows are }\end{array}$ & 38 & 14 & 52 & $18 \%$ \\
$\begin{array}{l}\text { You can see the shapes of the furniture in a } \\
\quad \text { room }\end{array}$ & 19 & 17 & 36 & $13 \%$ \\
$\begin{array}{l}\text { You can see well enough to recognise a friend } \\
\quad \text { if you get close to his or her face }\end{array}$ & 20 & 22 & 42 & $15 \%$ \\
$\begin{array}{l}\text { You can see well enough to recognise a friend } \\
\quad \text { who is at arm's length away }\end{array}$ & 26 & 13 & 39 & $14 \%$ \\
$\begin{array}{l}\text { You can see well enough to recognise a friend } \\
\quad \text { across the room }\end{array}$ & 11 & 10 & 21 & $7 \%$ \\
$\begin{array}{l}\text { You can see well enough to recognise a friend } \\
\quad \text { across the road }\end{array}$ & 2 & 5 & 7 & $2 \%$ \\
\hline Total & 177 & 108 & 285 & \\
\hline $\begin{array}{l}\text { b) Have you had this sight condition since } \\
\text { birth? }\end{array}$ & & & & \\
\hline $\begin{array}{l}\text { Yes } \\
\text { No }\end{array}$ & 72 & 32 & 104 & $36 \%$ \\
\hline Total & 109 & 76 & 185 & $64 \%$ \\
\hline c) At what age did you lose, or start to lose \\
$\quad$ your sight?
\end{tabular}

Overall, the largest proportion of participants had no light perception (26 per

cent), slightly more than is thought to be the case in the wider population (11).

In terms of the differences between the survey respondents and the 
interviewees, the latter tended to have more sight than the former. Very few differences were identified in questionnaire responses between respondents with different levels of visual impairment, or who started to lose their sight at different stages in their lives.

\section{Reading for pleasure}

The research clearly indicates the value which blind and partially sighted readers attribute to reading for pleasure, with the majority of participants (236 82 per cent) stating that reading for pleasure was 'very important' in their lives. The most frequently cited reason for reading for pleasure was to relax and/or relieve stress, mentioned by almost two-thirds of respondents (187 - 64 per cent) (Table 3).

\begin{tabular}{lrrrr} 
& & & \\
& Survey & Interview & Total & \\
\hline To relax/relieve stress & 156 & 31 & 187 & $64 \%$ \\
To get information/to find things out & 145 & 22 & 167 & $58 \%$ \\
To improve knowledge/for self-improvement & 127 & 14 & 141 & $49 \%$ \\
Escapism; from real life into a fantasy world & 105 & 32 & 137 & $47 \%$ \\
Out of curiosity/general interest & 111 & 8 & 119 & $41 \%$ \\
Other reason to like & 32 & 83 & 115 & $40 \%$ \\
Chance to use imagination & 106 & 4 & 110 & $38 \%$ \\
Mood boosting & 66 & 2 & 68 & $23 \%$ \\
Conversation starter/topic & 58 & 5 & 63 & $22 \%$ \\
\hline Total respondents & 182 & 108 & 290 & $100 \%$
\end{tabular}

Table 3 Reasons for reading for pleasure 
Forty-seven per cent of participants were motivated to read for pleasure to escape from real life into a fantasy world (Table 3) and when asked why reading for pleasure was important to them, 40 per cent of adults (115) cited escapism (Table 4). Marika (47), one of the six case study participants, is employed as a full-time braille transcriber and reads every day as it provides escapism and relaxation after a day at work: 'Just love going into other worlds, other people's stories, get away from this sometimes unpleasant world'. Thirty-eight per cent of participants (110) read to use their imagination. Other reasons for reading included a way of passing time when travelling or occupying the mind when undertaking routine chores. Learning was also an important reason for reading for pleasure, with key reasons including obtaining information (167), selfimprovement (141) and out of curiosity (119) - two-thirds of participants reported one or more of these (Table 3).

\begin{tabular}{lrrrrr} 
& Survey & Interview & Total & \\
\hline Enjoyment/feel good & 163 & 37 & 200 & $69 \%$ \\
Learn about new things & 132 & 28 & 160 & $55 \%$ \\
Insight into other cultures/different worlds/lives & 124 & 20 & 144 & $50 \%$ \\
Reduces stress & 113 & 13 & 126 & $44 \%$ \\
Escapism; from real life into a fantasy world & 97 & 18 & 115 & $40 \%$ \\
$\quad$ Companionship: talking about books read with & 92 & 7 & 99 & $34 \%$ \\
$\quad$ friends/family & & & &
\end{tabular}




\begin{tabular}{lrrrr} 
Like to be aware of current affairs & 91 & 7 & 98 & $34 \%$ \\
Other importance & 18 & 72 & 90 & $31 \%$ \\
Comfort/reassurance & 51 & 8 & 59 & $20 \%$ \\
Improve self-confidence & 36 & 1 & 37 & $13 \%$ \\
$\begin{array}{l}\text { Companionship: reading with children/other } \\
\quad \text { family members }\end{array}$ & 34 & 1 & 35 & $12 \%$ \\
\hline Total respondents & 181 & 108 & 289 & \\
Table 4 Why reading for pleasure is important & & &
\end{tabular}

Sixty-nine per cent of participants overall (200) reported that reading for pleasure was important because it provided enjoyment (Table 4). Learning about new things (160) and getting an insight into other cultures and lives (144) were the second and third most important reasons reported for reading, after general enjoyment (Table 4). Gordon, 81, reads braille and audio every day, often as much as 20 hours over the course of a week to maintain his interests in history and travel, 'I've also quite considerably extended my knowledge of other countries, of history, which I certainly wouldn't have done if I hadn't been reading a lot'.

Some differences were noted by gender. Twenty-eight per cent of women (46 out of 164 female participants) reported that they read for pleasure to boost their mood, compared to 16 per cent of men (20 out of 122 male participants). Similarly, 26 per cent of women (42 out of 164) reported that reading was 
important to them because it provided comfort and reassurance, compared to 12 per cent of men (15 out of 122).

Formats used when reading for pleasure

Eighty-five per cent of participants used multiple reading formats. Overall, the two most used formats were DAISY audio and audiobooks on CD (71 and 66 per cent respectively) (Table 5). Other popular formats used included DABs (41 per cent), braille (31 per cent) and audiobooks on cassette (27 per cent).

\begin{tabular}{lcc} 
& $\begin{array}{c}\text { Number of } \\
\text { respondents }\end{array}$ & Percentage of total \\
\hline DAISY Audio book & 205 & $71 \%$ \\
Audio book (CD) & 191 & $66 \%$ \\
Audio book (download) & 118 & $41 \%$ \\
Braille & 90 & $31 \%$ \\
Audio book (cassette) & 78 & $27 \%$ \\
Other formats & 68 & $24 \%$ \\
eBook & 63 & $22 \%$ \\
Large print & 32 & $11 \%$ \\
Giant print & 11 & $4 \%$ \\
\hline Total respondents & 286 & $100 \%$
\end{tabular}

Table 5 Reading formats used when reading for pleasure

EBooks were used by 22 per cent of all participants. The eBook format was a preference given in the online survey but was not sub-divided into eBook large 
print, eBook audio or eBook braille. Other ways of reading mentioned by participants included: books that had been scanned and uploaded onto a PC; other electronic texts with or without text-to-speech software; standard print, with or without magnification; being read to by friends or family; listening to reading materials from a USB memory stick on a device (such as a Boombox); and materials in Moon.

There were some differences noted by gender in the reading formats used men were more likely than women to read DAISY audiobooks (83 per cent of men compared to 62 per cent of women read these). Conversely, 34 per cent of women read audiobooks on cassette, compared to 18 per cent of men who used this format. In terms of age, younger respondents were more likely to use DAISY, eBooks and DABs than participants over the age of 65 . Janette, 54 , has retinitis pigmentosa and secondary glaucoma although an operation four years ago means that she can now see daylight. Currently employed as a part-time fundraiser, she reads three or four books at a time in a variety of audio and eBook formats. During the day she may use an iPad with voiceover, a DAISY $C D$ is usually her night time reading and when she goes away she uses a Victor Reader Stream DAISY player which she loads with DAISY audio, texts and DABs. Janette cherishes the choice the range of reading materials and devices that are now available give her: 'Often before getting a computer I only got 
books people thought were suitable for (the) blind to read now I can make personal choices and read books from around the world that suit me in a variety of formats'.

Participants were also asked to consider which one format they preferred and which one they used the most often (Table 6). Analysis of the data from the three questions relating to format revealed that a quarter of participants were not always able to read in the way that they preferred. A greater proportion of respondents reported reading using eBooks, audiobooks on CD and DAISY audio most frequently than said that these were their preferred formats.

Conversely, fewer respondents reported reading using large print, audiobooks on cassette, braille, DABs and other formats most often than said that these were their preferred formats. This situation is précised in the following quote from Linda who completed the online survey: 'Whilst preferring braille, more material is available in audio or DAISY formats so I use DAISY books and audiobooks from the library or from downloadable websites'. 
Preferred Most used

\begin{tabular}{lrrrr} 
& Number & $\%$ of total & Number & $\%$ of total \\
\hline DAISY Audio book & 120 & $42 \%$ & 138 & $49 \%$ \\
Audio book (CD) & 33 & $12 \%$ & 43 & $15 \%$ \\
Audio book (download) & 33 & $12 \%$ & 24 & $9 \%$ \\
Braille & 37 & $13 \%$ & 26 & $9 \%$ \\
Audio book (cassette) & 12 & $4 \%$ & 7 & $2 \%$ \\
eBook & 12 & $4 \%$ & 15 & $5 \%$ \\
Large print & 9 & $3 \%$ & 4 & $1 \%$ \\
Giant print & 4 & $1 \%$ & 3 & $1 \%$ \\
Other formats & 25 & $9 \%$ & 21 & $7 \%$ \\
\hline Total & 285 & $100 \%$ & 281 & $100 \%$
\end{tabular}

Table 6 Most used and preferred reading for pleasure formats

Sources of reading for pleasure material

In relation to obtaining reading materials, the top five overall sources were RNIB NLS (80 per cent of participants), public libraries (45 per cent), Calibre Audio Library (30 per cent), DABs (26 per cent) and gift (25 per cent) (Table 7$)$. Other sources included charitable organisations such as local and national Talking Newspapers, and free eBooks, for example, from the website Project Gutenberg. The responses to this question are likely to have been influenced by the method for recruiting participants, promoted by RNIB, Calibre Audio Library and to reading groups amongst others. 
On average, blind and partially sighted readers obtained their books from three different sources each. When asked to consider their main source, 66 per cent of participants borrowed from RNIB NLS, 13 per cent from public libraries, seven per cent bought DABs and four per cent accessed them through Calibre Audio Library (Table 7).

\begin{tabular}{lrrrr} 
& \multicolumn{2}{c}{ Source used } & \multicolumn{2}{c}{ Main source } \\
& Number & $\%$ of total & Number & $\%$ of total \\
\hline Borrow from RNIB National Library Service & 230 & $80 \%$ & 188 & $66 \%$ \\
Borrow from the public library & 130 & $45 \%$ & 36 & $13 \%$ \\
Borrow from Calibre audio library & 86 & $30 \%$ & 11 & $4 \%$ \\
Buy an online download & 75 & $26 \%$ & 19 & $7 \%$ \\
Gift & 72 & $25 \%$ & 2 & $1 \%$ \\
Buy from a shop online & 54 & $19 \%$ & 6 & $2 \%$ \\
Buy from RNIB & 47 & $16 \%$ & 4 & $1 \%$ \\
Borrow from other charitable source & 45 & $16 \%$ & 6 & $2 \%$ \\
Other source & 46 & $16 \%$ & 12 & $4 \%$ \\
Buy from a shop & 41 & $14 \%$ & - & - \\
Borrow from a friend & 41 & $14 \%$ & - & - \\
Already in the house & 25 & $9 \%$ & 3 & $1 \%$ \\
\hline Total & 288 & $100 \%$ & 287 & $100 \%$
\end{tabular}

Table 7 Sources of reading for pleasure materials

Ninety six per cent of participants read fiction whilst 76 per cent read non-fiction and 11 per cent read poetry. Other material was mentioned by 19 participants 
(seven per cent of the total), the majority of which was newspapers and magazines, by 15 participants. However, since reading magazines and newspapers was not explicitly investigated in this study, this figure is merely illustrative of those participants who wished to point this out. Fiction is also the most popular type of reading in the general population. Statistics from the Chartered Institute of Public Finance and Accountancy (CIPFA) indicate that approximately two-thirds of book lending by public libraries in the UK is fiction (68 per cent) compared to one-third non-fiction (32 per cent) based on data from the Public Library Actuals survey 2011-12 (CIPFA, 2012).

Blind and partially sighted adults chose their reading materials by known author (67 per cent), recommendations from friends (53 per cent), previous experience (46 per cent), availability (45 per cent), and genre (42 per cent) (Table 8 ). Other sources detailed included RNIB New Books publication, RNIB selection and other RNIB resources such as the online catalogue or website; Calibre Audio Library publications or selection; titles heard, reviewed or recommended on the radio; reading group recommendations; and the actual appearance of the book or audiobook including its cover or blurb. Over a quarter of participants (73) drew on recommendations from library staff (26 per cent). 
Total

No. $\%$ of total

\begin{tabular}{lcc}
\hline Known author & 191 & $67 \%$ \\
Friend recommendation & 152 & $53 \%$ \\
Previous experience & 131 & $46 \%$ \\
Availability in my preferred format & 129 & $45 \%$ \\
Genre & 120 & $42 \%$ \\
Other means of choosing & 114 & $40 \%$ \\
Accessibility & 85 & $30 \%$ \\
Family recommendation & 83 & $29 \%$ \\
Library recommendation & 73 & $26 \%$ \\
Advertising / publicity & 57 & $20 \%$ \\
Mood & 46 & $16 \%$ \\
Website recommendation & 40 & $14 \%$ \\
Length & 29 & $10 \%$ \\
Shop recommendation & 7 & $2 \%$ \\
\hline Total respondents & 285 & $100 \%$
\end{tabular}

Table 8 Selection of reading for pleasure materials

Time spent reading for pleasure

Ninety-five per cent of participants read for pleasure more than once a week.

Over half of participants read for more than 10 hours a week (57 per cent) and 22 per cent read between seven and 10 hours a week (Table 9). 


\begin{tabular}{llrr} 
& & Number & $\%$ of total \\
\hline More than once a week & More than 10 hours & 161 & $57 \%$ \\
& Between 7 and 10 hours & 62 & $22 \%$ \\
& Between 3 and 6 hours & 41 & $14 \%$ \\
& Less than 3 hours & 4 & $1 \%$ \\
\cline { 2 - 4 } & All more than once a week & 268 & $95 \%$ \\
About once a week & & 7 & $2 \%$ \\
About once a fortnight & & 3 & $1 \%$ \\
About once every 3-4 weeks & 2 & $1 \%$ \\
About once a month & & 2 & $1 \%$ \\
Less often but read occasionally & 1 & $0 \%$ \\
\hline Total & & 283 & $100 \%$
\end{tabular}

Table 9 Frequency of reading for pleasure

Respondents were asked whether the amount of time they spend reading for pleasure had changed in the last five years. For 36 per cent of all participants there had been no change, for 12 per cent of participants there had been a decrease in the amount of time they spent reading for pleasure whilst for 52 per cent of participants there had been an increase. Participants were asked for the reasons for any changes, and most offered more than one. Of those who felt the amount of time they spent reading for pleasure had increased over the last five years, 60 per cent of participants felt that they had more time available, 42 per cent of participants said there are more formats available now and 33 per cent of participants enjoy reading more now. 


\section{Reading groups}

Thirty nine per cent of participants overall belonged to a reading group, although it should be remembered that reading groups for blind and partially sighted adults were targeted as part of the recruitment of the interview sample. Survey respondents were less likely to belong to a group - 22 per cent (41) compared to 66 per cent of interviewees (71), which may be a more accurate representation of reading group membership amongst blind and partially sighted adults. Women were more likely than men to belong to a group - 51 per cent (83 out of 163 women) compared to 30 per cent of men (28 out of 92 men) Adults with greater degrees of visual impairment and those who started to lose their sight as children were less likely to belong to a reading group.

Reading group members reported a variety of perceived benefits from their participation (Table 10). Social contact and integration was a key outcome - 65 per cent (73) of reading group members felt that one of the best things about belonging to a group was the opportunity to socialise. Membership of a reading group also supported learning and skills development. Sixty three per cent (71) said that one of the best things about such groups was that they were introduced to a wider range of books and authors, while for 61 per cent it provided an opportunity to talk about what they had read. More than half (54 per cent) said the reading group gave them a chance to meet new people. Mike, 
one of the six case study participants, attends a Visually Impaired Reading Group at Berkhamsted library, once every six weeks on a Tuesday afternoon; 'I get picked up and they drive me in the community bus and they pick up other people'. All the members of the group use audiobooks except Mike who reads print. The members of the group share their opinions of what they have read; 'We always have a laugh and a chinwag and then we talk about the books'. For Mike, 75, who lives alone, the meeting is 'a social gathering really, you get a cup of tea and a couple of biscuits'. In addition, the group provides him with an opportunity to meet with other blind and partially sighted adults and understand 'how other people get on with their visual impairments'. Mike's partner of 30 years, Sheila, died last year, and reading is 'a mental comfort if you like, to read the books she bought me. It's really just part of grieving'. 
Total

Opportunity to socialise

73

$65 \%$

Helps me explore big issues/experiences/share ideas with others

71

$63 \%$

Introduces me to a wider range of books and authors

$63 \%$

Provides an opportunity to talk about what I've read

68

$61 \%$

Makes me feel part of a group/community

61

$54 \%$

Chance to meet new people

54

$48 \%$

The group is accessible to me

45

$40 \%$

Supportive neutral setting

35

$31 \%$

Chance to be creative

10

$9 \%$

Gives me confidence to speak in front of others

10

$9 \%$

Other best thing about group

10

$9 \%$

Allows me to escape to another world

6

$5 \%$

Total

112

Table 10 Best things about belonging to reading groups

\section{Discussion}

The results detailed above reveal that reading for pleasure is a pursuit many blind and partially sighted adults' value; 82 per cent of study participants agreed that reading for pleasure was 'very important', to which many dedicate more than 10 hours a week. This would appear to endorse figures from 1999 which 
found that the majority of those questioned in a study of audiobook users by RNIB, regarded reading as a very important leisure activity with 63 per cent spending more than two hours on reading per day (Chartres, 1999 in Kinnell et al., 2000).

The pleasure of reading

Blind and partially sighted adults' reasons for reading appear to support findings from research with sighted readers. For example, a UK study with data drawn from 29 focus groups with readers, discovered that escapism was a key motivator but one which had been viewed disparagingly in the past, and yet 'it was clear that people felt, for varying reasons, they needed to be able to escape their day-to-day life experience, and the pressures of living in the twenty-first century' (Toyne and Usherwood, 2001:27). Moreover, it enabled them to 'abandon the here and now' (Gerrig, 1993 in Usherwood and Toyne, 2002), providing a distraction from reality, an escape from loneliness and depression and to alter their mood (Toyne and Usherwood, 2001). Similarly, research for Arts Council England based on workshops with 40 adult readers who were asked to keep a reading diary for one week, revealed that reading for pleasure positively affected their views of the world, offering 'relaxation, stimulation and broadening of the mind, new perspectives on one's own life and inspiration' (Creative Research, 2009:8). In our six case studies, it was clear 
that reading was a purposeful pastime which enabled adults to escape the constraints of their disability. Avril, now 60 , was in her early 40 s when her sight began to change as a result of macular dystrophy in both eyes, and reading has 'been an escape from all the mundane things that go on in my life. It means I can completely step outside of everything else which I like. It's offered me an escape from dealing with things when I don't want to'. This resonates with the views expounded by Soheli Begum, a public librarian in Canada who critiqued the concept of escapism in reading for pleasure. She suggested: 'Leisure reading can be used as a means of escaping boredom, but can also be a critical tool for self-preservation in far more turbulent environments. Additionally, leisure reading transports readers away from current situations and also shapes and affects how they view and respond to future events. The transformative nature of leisure reading is such that it can be considered by many a means of maintaining humanity and a sense of self in sometimes uncertain and dangerous settings' (Begum, 2011:740).

Ross remarked in her review of the data published in scholarly journals as well as her own research findings, that reading brings a sense of surrender for some adults - the feeling of being seduced or enthralled by the text: 'Avid readers report that when reading is especially pleasurable, it is as if they have fallen under a spell' (Ross, 2006:151). There is pleasure to be gained from reading 
large amounts of text quickly and easily. Ross refers to 'flow', to describe when adults are effortlessly engaged in reading to the extent that other worries and concerns disappear (Csikszentimihalyi, 1990 in Ross, 2006). Reading may also stir positive memories from childhood of being read to, of parents' voices, snuggling up; of the pride accompanying learning to read. Books are associated with providing comfort and security (Ross 2006). Gordon, one of the six case study participants, lost his sight during an air raid in the Second World War. Now retired, he lives alone and describes reading as offering him an opportunity to 'escape into a family, that's one of the occasions when it helps to overcome the loneliness of living alone'. Following the death of his wife six years ago, Gordon has found that reading has 'become more important... because there are times about the house such as mealtimes. Mealtimes are really family times but my meals are on my own now. I always have a book going'. Reading for reassurance emerged in Howard's study of students aged 12 to 15 years in Canada based on focus group discussions with 68 sighted young people; 'For many teens, pleasure reading can be reassuring, making them feel better about themselves and their own lives' (Howard, 2011:53).

Begum considered the transformative nature of reading for pleasure in that it may be used to help the reader cope with change which is psychologically uncomfortable: 'It is not always a mindless pleasure that readers seek through 
escapist reading; it is often a meaningful change, a meaningful transformation that they are after, even if this transformation comes about through painful realizations and soul searching' (Begum, 2011:744). Three of the six case study participants had experienced the loss of their spouse in recent years and reading had played a fundamental role in the grieving process. At first, Janette, whose husband Tom died eight years ago, could not bring herself to read and it was the Talking Books which 'kept me going...I tried to move on a bit and it's really difficult and the reading side of things has definitely helped. It's a comfort blanket. It's always been with me. I've certainly used the Talking Books to help. They've gee'd me up sometimes when l've felt down. Also my choice of books, I've tried to choose books that would give me impetus to move on a little bit more. In a funny sort of way the Talking Books were like my counselling service. I tried to choose books that would make me happy and books that made me understand myself a bit better. I don't know what I would have done without them at that time'.

The pain of reading The majority of blind and partially sighted readers were positive about their reading experiences but they experienced frustrations in accessing all the material they wanted to read. In our study, respondents used multiple reading formats in different situations, or for different types of material. Participants were 
engaged via reading groups and websites promoting reading materials to blind and partially sighted readers and we did therefore talk to keen readers. It appears that they diversified their reading format options and sources in order to get the widest range of material possible. RNIB NLS was the main source of materials for reading for pleasure of 66 per cent of all participants in this study and 80 per cent used the service. The DAISY audio format provided by RNIB NLS, in particular, was well-liked since it is compact, unabridged with good quality narration.

In the UK, a small minority of books published are converted into accessible formats and if they are transcribed, there is usually a time delay. Frustration was expressed by some participants in relation to the lack of reading material in braille and the time lag between print publications and their braille counterparts making an appearance in RNIB NLS. Marika, 47, one of the six case study participants primarily reads braille. Born with a rare form of glaucoma Bartholomaus, Marika had almost 70 operations on her eyes most of which took place before the age of seven. She learnt braille as a child and is passionate about reading, having been a member of the RNIB NLS since she was young. Marika relies upon the RNIB NLS for her reading materials in braille, 'I wouldn't be without them' but she is sometimes frustrated when books aren't available in braille, 'It is a shame sometimes when you can't have a sequel or follow-up 
book'. It was also highlighted that whilst many fiction titles are available in audio format, non-fiction and foreign literature are hard to obtain: 'Even in the library there is so much audio material which is popular novels and so little on nonfiction so I've kind of been edged into a reader of novels without wanting to be' (David, 75). This constraint was also noted in a recent small scale study undertaken by RNIB NLS with 33 blind and partially sighted adult participants during Make A Noise in Libraries Fortnight (MANIL) in June 2012; 'Many found the range of large print and audio book titles was limited, particularly for keen readers and those looking for non-fiction or something a bit different' (RNIB NLS, 2012:5).

A minority of readers purchased books online from the USA or Australia in order to access certain titles. Some also accessed texts illegally. Annoyance was expressed at restrictions preventing RNIB and other charitable organisations in sourcing accessible reading materials, for example, from other countries. The World Blind Union highlights that 'The national nature of copyright law prevents the import and export of accessible books' and removing this legal barrier would allow, 'Many hundreds of thousands of books to circulate between blind people's organisations in different countries' (WBU, 2011). Since 2004 the World Intellectual Property Organization's (WIPO) Standing Committee on Copyright and Related Rights (SCCR) have been deliberating whether certain 
copyright exemptions should be harmonised internationally. In June 2013, WIPO will convene a conference in Morocco to complete negotiations on a pact to improve access to copyrighted works for people who are blind and partially sighted as well as print disabled, globally (WIPO, 2012).

EBooks were used by one-fifth of all participants in our study. Research from 2011 reveals that eBooks make a significant difference to accessibility of books - just six per cent of books published in the UK were accessible in any traditional format (i.e. hard copy large print, human speech audio or hard copy braille) but if eBooks are included this increases to 20 per cent (Greenwood, White \& Creaser, 2011). If only the most popular titles are considered, 73 per cent of the books in the top 1000 of 2011 were available as an accessible eBook, but only 17 per cent were available as fully accessible hard copy versions of titles (Creaser, 2012). Some blind and partially sighted readers use eBook readers to enlarge text, read using electronic braille or listen to audiobooks whilst some use the synthetic speech audio option in order to listen to the book. Avril, for example, tends to read eBooks most frequently since she can enlarge the text to 16 point font size. The advent of portable, hand-held eBook readers has made a huge difference to Avril's fiction reading especially as she finds it uncomfortable to sit at a PC to read. She perceives that 'The Kindle has opened up a huge, big library for me really' although she found that 
non-fiction is not as readily available in eBook format, 'occasionally there's some'. Research into the accessibility of the most popular books of 2011 highlighted that the text-to-speech option is not always enabled on eBooks which prevents blind and partially sighted readers from reading certain texts in audio formats (Greenwood et al., 2011).

The pleasure of reading with others

Public libraries were a source of reading materials for almost half of participants whilst approximately one quarter drew on recommendations from public library staff when choosing their books. Almost all the public library reading group members and members of reading groups run by charitable organisations questioned in our study, were very appreciative of the opportunity that the group provided them with in terms of meeting other people, talking about books and finding out about new authors and titles: 'It's a very pleasurable thing to do. You come together with 10 to 15 people that you see once a month... I started about 10 years ago... I have to say it is because of the staff and the helpers at the library that make it what it is' (Jean, 92).

Indeed, the opportunity of social contact for blind and partially sighted adults offered by reading groups may be especially important when ' 44 per cent of 
blind and partially sighted people report that they feel "moderately" or "completely" cut off from the people and things around them' (RNIB, 2012b:14). This supports the findings of research into the experiences of blind and partially sighted adults attending reading groups (Hyder, 2008a, 2008b, 2009). Hyder gathered data on reading groups for blind and partially sighted adults based on a questionnaire as well as attending two local groups and interviewing five members and two librarians over the course of a year. Hyder tried to ascertain whether reading was more important to the group members or whether it was the social aspect of the group which was the greater attraction. She found that '33 of the 37 respondents (89\%) said that they read/listened to other books beside the one required for the group...VIP group members are not simply seeking an opportunity for social interaction but have a genuine interest in reading' (Hyder, 2008a:17).

Reading research has revealed that choice is an essential factor in relation to enjoyment (Ross, 2006). When choosing what to read, Ross suggests adults consider a number of elements including, for example, the reading experience they desire; alerting sources to find out about new books such as browsing, recommendations from family and friends, and reviews as well as physical clues on the book itself such as the author, cover, genre, publisher or title (2006). A source of frustration for some participants in our study was the way in which 
their opportunity to choose reading materials was sometimes hampered by the way materials were presented in their local public library. Audiobooks, on CD and cassette (12) were the format of choice for 16 per cent of participants but sometimes stickers and barcodes on the case obscured the book blurb. If the text was visible, it still presented a barrier if it was in standard or smaller print: 'If I go to the library and choose it [audiobook] myself they know it's for someone that can't see but when you turn it over it's in ordinary print to tell you what the story is... so I have to go by the picture on the front' (Maureen, 74).

These sentiments were voiced by users of public libraries during MANIL in the survey study by RNIB NLS who found they could easily locate the relevant section in the library where materials for blind and partially sighted readers were shelved and/or displayed but selecting individual items was more difficult because they were not always presented in a way which best helped the reader make a decision, such that the majority relied on staff to help them: 'Several people commented on the absence of large print or braille labels and at a couple of libraries CDs were not shelved by genre but just fiction or non-fiction, leaving the customer to browse through everything. Several people noted that it is very difficult to read audio book titles with poor sight if they are stored on a bottom shelf near the ground!' (RNIB NLS, 2012:4). Some participants in our study developed their own approaches to selecting reading materials at their 
library, for example; 'If I go to the library it's a bit of an elaborate procedure but I still choose. I take along a CD player and some earphones and try them at random to see if I've had them before or if they are what I want' (Bill, 68) whilst others required assistance: 'I usually go into the library with a sighted person and they read the back to me' (Mandy, 24). Indeed, in the RNIB NLS MANIL study, 'there was a strong reliance on staff or a sighted companion to read out information to enable book choices to be made' (RNIB NLS, 2012:4).

The issue of choosing what to read was also noted in relation to reading groups. Janette, 54, one of the six case study participants, attends a VIP reading group at her local public library where the librarian rather than the group members choses the books, which she feels is 'A little bit like going back in time'. Other reading group participants were also ambivalent about the choice of books: 'I enjoy talking about the books, don't always enjoy the book they pick for us to read however' (Steve, 61). Nonetheless, some readers welcomed the variety since it meant they tried new authors and genres: 'Suggesting the different authors, it's great, wonderful. The one I belong to is at a public library itself which is great as I'd given up going as I was getting more blind' (Mary, 81).

Growing numbers of public library services are now loaning or 'e-lending' eBooks to library users which provides blind and partially sighted adults with another potential source of reading materials (13). The Chartered Institute of 
Library and Information Professionals (CILIP) found that approximately 142 public library authorities were offering eBooks in 2012 (CILIP, 2012a). As one participant explained, public library e-lending presented them with another source of books: 'I also use Essex Library Services as a download facility to download electronic books. Their content is sometimes different to what the RNIB has' (Steve, 48).

Public libraries supporting blind and partially sighted adult readers In addition to traditional reading groups, some participants attended events at their public library specifically aimed at blind and partially sighted adults including author events or sessions facilitated by library staff where they described the publications in a variety of accessible formats: 'Sometimes the library holds events where a writer comes to the main library in Stockton and gives a talk about their writing. The library will then have as many of the audiobooks as well as the ordinary books as possible for people to go through. Some of these people will read extracts of their own books and that can sometimes trigger an interest that I wouldn't otherwise have had' (Chris, 64).

Other examples of ways to assist blind and partially sighted readers select their books included the PenFriend device which is being used by the Isle of Wight library service. The PenFriend can be programmed to read out the details of an 
audiobook including its title, author and content - just like reading the cover of a book, using an audio label on the spine. As one participant explained: 'I find it very difficult because they're [large print books] all on end. Without pulling each one out... I can't glide along a shelf and read what they say, it's easier if I hear of something recommended by one of the group and order it... They're having this thing called a PenFriend which is only for the tapes or discs but maybe it might incorporate the large print books one day. It tells you the title, author and the preface of the book. How brilliant is that if you can't see? Don't have to bother people... be more independent' (Claudine, 71).

Similarly, some participants mentioned 'reading buddies' where volunteers helped them pick out audiobooks or large print books: 'There is a reading buddy. It's interesting because she gives us descriptions of her favourite books and she tells us what other people in the library like. Her job is to help people who can't see to pick audiobooks or large print' (Chris, 64).

In 2011, Share the Vision, the Society of Chief Librarians and the Scottish Library \& Information Council published Six Steps to library services for blind and partially sighted people, a call to public libraries to improve the services they provide to blind and partially sighted library users (The Society of Chief Librarians, 2011). The steps include assessing the reading needs of blind and partially sighted users, providing local collections of audiobooks and large print, 
and designating a 'champion' for the reading needs of blind and partially sighted people. Another of the Six Steps is the website Reading Sight (14) aimed at library staff which has practical information about how staff can guide library users with sight loss around the library, for example. Recent figures reveal that 185 of 205 public library authorities in the UK have signed up to Six Steps (RNIB, 2012).

\section{Conclusion and Recommendations}

The key finding of our research is that blind and partially sighted adult readers are not very different from sighted readers, in terms of their reasons for wanting to read for pleasure and its effects. However, the types of reading materials used by visually impaired readers and their access to them is different. Analysis of the data from the three questions relating to format in our study revealed that a quarter of participants were not always able to read in the way that they preferred. We recommend greater collaboration between producers in accessible formats, publishers and specialist library services to supply better reading materials to increase the availability of accessible formats, including eBooks, beyond the most popular titles in order to benefit blind and partially sighted adults who utilise library services to obtain their reading materials. 
Although this was a small-scale study conducted wholly in the UK it builds upon and confirms findings from the reading for pleasure literature. Changing technologies are impacting positively on access to reading materials but there is much libraries can do to help facilitate that choice for blind and partially sighted readers. Reading groups, facilitated by public libraries, local and national charitable organisations, provide a valuable service not only in terms of facilitating access to reading materials but as an opportunity for readers to engage in debate as well as a social occasion for blind and partially sighted adults to meet with others in a similar situation within a supportive environment. We recommend that they are promoted to local support groups to increase access to the benefits they offer.

Furthermore whilst public library services generally provide accessible materials the presentation of those materials must also be accessible, although issues such as the size of text on book covers and audiobook CD inserts are beyond the control of libraries. However, libraries are able to control the ways in which materials are shelved and presented. We recommend that libraries draw upon the guidance offered in Six Steps, for example, to give blind and partially sighted adult readers the opportunity to choose what they want to read which is an integral part of the reading experience. As Beech highlights, 'Blind and partially sighted people are as diverse as sighted people. They study, they have 
jobs, they vote in elections and they pursue a myriad of hobbies and interests. They want to read the same books as sighted people. They also want to choose books independently' (Beech, 2007:6).

\section{Acknowledgements}

The authors would like to thank the RNIB Steering Group, LISU colleagues, and all those who promoted the call to participate. We would especially like to thank the interviewees and survey respondents. The comments and suggestions of the reviewers were also appreciated.

\section{Funding}

This research was commissioned by the Royal National Institute of Blind People (RNIB).

\section{Notes}

(1) Creaser C, Spacey R and Hicks D (2012) Assessing the Impact of Reading for Blind and Partially Sighted Adults. Available at: http://www.lboro.ac.uk/microsites/infosci/lisu/downloads/rnib-impact-ofreading-report.pdf(accessed 4 April 2013).

(2) This research used a simple definition of reading for pleasure based on a review of the literature - 'reading for enjoyment, whatever it is you read'. 
(3) Creaser C, Spacey R and Hicks D (2012) Assessing the Impact of Reading for Blind and Partially Sighted Adults: supplementary information. Available at:

http://www.lboro.ac.uk/microsites/infosci/lisu/downloads/rnib impact of $r$ eading supplementary info.pdf (accessed 4 April 2013).

(4) Figures from CILIP (CILIP, 2012b) revealed that of the public library authorities responding to their survey (53 per cent), there was a net loss of over $£ 39$ million from total revenue expenditure between 2010-11 and 2011-12 in England, Wales and Northern Ireland from a budget of over $£ 564$ million. This represented a net cut in expenditure of approximately seven per cent of the total relevant expenditure of responding authorities.

(5) According to the website Public Libraries News 300 libraries (263 buildings and 37 mobiles) are currently under threat or have been closed/left council control since April $1^{\text {st }} 2012$ out of approximately 4612 in the UK. http://www.publiclibrariesnews.com/

(6) See for example, Clark and Rumbold (2006); Dungworth et al. (2004); Usherwood and Toyne (2002).

(7) http://readinggroups.org/ 
(8) Share the Vision is a partnership of UK libraries and library organisations that work together to improve the accessibility of library services for print disabled people. http://www.share-the-vision.org.uk/

(9) Women are more likely to have age-related visual impairment (RNIB, 2012).

(10) In relation to the wider demographic of blind and partially sighted adults, there are statistics available in relation to the age distribution of adults who are registered blind and partially sighted but since this is a voluntary scheme, the data is not usually used as an accurate indication. NHS figures from 2011 suggest that 13 per cent of blind adults are aged between 18 and 49, 11 per cent between 50 and 64; nine per cent aged 65 to 74 and 64 per cent aged over 75 (NHS Information Centre, Adult Social Care Team, 2011). According to RNIB, 1 in 5 or 20 per cent of adults aged over 75 in the UK have sight loss (RNIB, 2012).

(11) Approximately 18 per cent of blind people are totally blind - most can distinguish between light and dark (Reading Sight, 2013).

(12) Audiobooks on cassette are still popular amongst blind and partially sighted readers but their production is in decline, for example, only 12 per cent of the top 1000 books of 2011 were available unabridged in cassette format (Creaser, 2012). 
(13) However, public library e-lending is thwarted in some respects since users cannot borrow eBooks using an Amazon Kindle. In September 2012 Culture Minister Ed Vaizey announced an independent review of eBook lending in England, the Sieghart Review which reported in March 2013. It argues that e-lending should be free at the point of use and that public libraries should offer e-lending remotely to their readers: https://www.gov.uk/government/publications/an-independent-review-of-elending-in-public-libraries-in-england

$$
\text { http://readingsight.org.uk/ }
$$

\section{References}

Access Economics (2009) Future sight loss UK (1): The economic impact of partial sight and blindness in the UK adult population. Full report. Report prepared for RNIB by Access Economics Pty Limited. Report, RNIB, UK. Available at:

http://www.rnib.org.uk/aboutus/Research/reports/2009andearlier/FSUK Report. pdf (accessed 30 January 2013).

Beech P (2007) To read is to see. Public Library Journal 22(3):6-7,10.

Begum, S (2011) Readers' advisory and underestimated roles of escapist reading. Library Review, 60(9):738-747. 
CILIP (2012a) Ebook lending by public libraries. Available at:

http://www.cilip.org.uk/get-

involved/policy/statements\%20and\%20briefings/Documents/Ebooks\%20and\%2

Opublic\%20libraries\%20-\%20brief\%20overviewv2.pdf (accessed 30 January 2013).

CILIP (2012b) The eye of the storm? A survey of public library authorities in England, Wales and Northern Ireland 2011-2012. Report, CILIP, UK. Available at: http://www.cilip.org.uk/get-

involved/policy/Documents/CILIP Public library survey 2011-

2012 Eye of the storm.pdf (accessed 30 January 2013).

CIPFA (2012) UK Annual Libraries Survey. Report, CIPFA, UK.

Clark C and Rumbold K (2006) Reading for Pleasure. A research overview.

Report, National Literacy Trust, UK. Available at:

http://www.literacytrust.org.uk/assets/0000/0562/Reading pleasure 2006.pdf (accessed 30 January 2013).

Creaser C (2012) Accessibility of top 1,000 titles in 2011. Report. Report, RNIB, UK. Available at: 
http://www.rnib.org.uk/professionals/Documents/Accessibility Top 10002011

Research report.pdf (accessed 30 January 2013).

Creative Research (2009) The future of reading: A public value project. Report, Arts Council England, UK. Available at:

http://www.artscouncil.org.uk/media/uploads/Future-Reading-Report.pdf

Davies JE, Wisdom S and C Creaser (2001) Out of sight but not out of mind. Visually impaired people's perspectives on library \& information services. LISU Occasional Paper no.29. Report, LISU, UK. Available at: http://www.lboro.ac.uk/departments/ls/lisu/pages/publications/stvtextonly.html (accessed 30 January 2013).

Douglas G, Corcoran C and S Pavey (2006) Network 1000. Opinions and circumstances of visually impaired people in Great Britain: report based on over 1000 interviews. Report, Visual Impairment Centre for Teaching and Research, UK. Available at: http://www.birmingham.ac.uk/Documents/college-socialsciences/education/victar/network1000-survey1-opinions-circumstances.pdf (accessed 30 January 2013).

Dungworth N, Grimshaw S, McKnight C and A Morris (2004) Reading for pleasure?: A summary of the findings from a survey of the reading habits of 
year 5 pupils. New Review of Children's Literature and Librarianship, 10(2):169188.

Greenwood H, White S and C Creaser (2011) Availability of accessible publications: 2011 Update. Report, RNIB, UK. Available at http://www.rnib.org.uk/professionals/Documents/2011 Accessibility Update fin al report.pdf (accessed 30 January 2013).

Howard V (2011) The importance of pleasure reading in the lives of young teens: Self-identification, self-construction and self-awareness. Journal of Librarianship and Information Science, 43(1):46-55.

Hyder E (2008a) Play it by ear. Reading groups for VIPs. Public Library Journal, 23(2):16-18.

Hyder E (2008b) VIP reading groups. Research Intelligence 103:17-18.

Hyder E (2009) Readers are very important people. English in Education, 43(3): 226-240.

Kinnell M, Yu L and C Creaser (2000) Public library services for visually impaired people. Report, LISU, UK. Available at:

http://www.lboro.ac.uk/departments/ls/lisu/downloads/op26.pdf (accessed 30 January 2013). 
NHS Information Centre, Adult Social Care Team (2011) Registered Blind and Partially Sighted People Year ending 31 March 2011 England. Available at: https://catalogue.ic.nhs.uk/publications/social-care/vulnerable-adults/peop-regiblin-part-sigh-eng-11/peop-regi-blin-part-sigh-eng-11-rep.pdf (accessed 30 January 2013).

Reading Sight (2013) What can customers with sight problems see? Available at:

http://readingsight.org.uk/accessible libraries/guidance for library services/sta ff training development/what can customers with sight problems see/ (accessed 30 January 2013).

RNIB (2012a) Key information and statistics. Available at:

http://www.rnib.org.uk/aboutus/research/statistics/Pages/statistics.aspx (accessed 30 January 2013).

RNIB (2012b) Shaping our future. Listening to your views on the future direction of the RNIB group of charities. Available at:

http://www.rnib.org.uk/aboutus/Documents/shaping our future booklet.pdf (accessed 30 January 2013).

RNIB National Library Service (2012) A Six Steps survey of public library services for blind and partially sighted people. Report, RNIB, UK. Available at: 
http://readingsight.org.uk/blog/six steps survey full report/ (accessed 30 January 2013).

Ross CS, (2006) 'Adult readers'. In: Ross CS, McKechnie L and P Rothbauer (2006) Reading Matters: What the Research Reveals about Reading, Libraries, and Community. Westport: Libraries Unlimited, pp. 133-241.

The Reading Agency (2008) Reading Groups in Libraries Mapping Survey Findings - England and Wales. Report, The Reading Agency, UK.

The Society of Chief Librarians (2011) Six Steps to library services for blind and partially sighted people. Available at: http://www.goscl.com/six-steps-to-libraryservices-for-blind-and-partially-sighted-people/ (accessed 30 January 2013).

Toyne J and B Usherwood (2001) Checking the books. The Value and Impact of Public Library Book Reading. The University of Sheffield: Centre for the Public Library and Information in Society, Department of Information Studies.

Usherwood B and J Toyne (2002) The value and impact of reading imaginative literature. Journal of Librarianship and Information Science, 34(1):33-41.

World Blind Union (2011) Brief On WIPO Treaty. Available at:

http://www.worldblindunion.org/English/our-work/our-priorities/Pages/Brief-OnWIPO-Treaty.aspx (accessed 30 January 2013). 
World Intellectual Property Organization (2012) WIPO Advances Toward Treaty to Facilitate Access to Published Works by Persons with Print Disabilities, Morocco Offers to Host Diplomatic Conference. Available at: http://www.wipo.int/pressroom/en/articles/2012/article 0026.html (accessed 30 January 2013).

Appendix 1

Interview/survey questions

\section{Section 1: Reading for pleasure - purpose and value}

1. Why do you like to read for pleasure?

Escapism; from real life into a fantasy world

To relax/relieve stress

Mood boosting

Chance to use imagination

To get information/to find things out

Out of curiosity/general interest

To improve knowledge/for self-improvement

Conversation starter/topic

Other

2. Why is reading for pleasure important to you?

Enjoyment/feel good

Escapism; from real life into a fantasy world 
Companionship: reading with children/other family members

Companionship: talking about books read with friends/family

Insight into other cultures/different worlds/lives

Learn about new things

Improve self-confidence

Comfort/reassurance

Reduces stress

Like to be aware of current affairs

Other

3. How important is reading for pleasure to you? (I have a scale I will read out for you)

\begin{tabular}{|l|l|c|c|c|c|}
\hline $\begin{array}{c}\text { Don't } \\
\text { know }\end{array}$ & $\begin{array}{c}\text { Not at all } \\
\text { important }\end{array}$ & $\begin{array}{c}\text { Slightly } \\
\text { important }\end{array}$ & $\begin{array}{c}\text { Fairly } \\
\text { important }\end{array}$ & $\begin{array}{c}\text { Quite } \\
\text { important }\end{array}$ & $\begin{array}{c}\text { Very } \\
\text { important }\end{array}$ \\
\hline & & & & & \\
\hline
\end{tabular}

4. Which reading formats do you use?

Braille

Large print

Giant print

Audio book* on cassette

Audio book on $C D$

DAISY Audio book

Audio book download e.g. MP3

eBook 
Other

5. Of those reading formats:

\begin{tabular}{|l|l|l|}
\hline & a) $\begin{array}{l}\text { Which do you prefer? } \\
\text { (tick one) }\end{array}$ & b) $\begin{array}{l}\text { Which do you use the } \\
\text { most often? (tick one) }\end{array}$ \\
\hline Braille & & \\
\hline Large print & & \\
\hline Giant print & & \\
\hline Audio book* on cassette & & \\
\hline Audio book on CD & & \\
\hline DAISY audio book & & \\
\hline $\begin{array}{l}\text { Audio book download e.g. } \\
\text { MP3 }\end{array}$ & & \\
\hline eBook & & \\
\hline Other & & \\
\hline
\end{tabular}

6. Could you tell me why?

Accessibility

Size

Convenience

Cost

Other

7. Where do you get your reading material from?

Borrow from the public library

Borrow from Calibre audio library 
Borrow from RNIB National Library Service

Borrow from other charitable source

Borrow from a friend

Buy from a shop

Buy from a shop online

Buy an online download

Buy from RNIB

Gift

Already in the house

Other

8. What would you say is the main source of your reading material? Borrow from the public library

Borrow from Calibre audio library

Borrow from RNIB National Library Service

Borrow from other charitable source

Borrow from a friend

Buy from a shop

Buy from a shop online

Buy an online download

Buy from RNIB

Gift

Already in the house

Other 
Section 2: Reading for pleasure - choice and frequency

9. What do you like to read for pleasure? Fiction

Non-fiction

Poetry

Other

10. How do you choose what you want to read? Known author

Mood

Previous experience

Accessibility

Length

Genre

Library recommendation

Shop recommendation

Website recommendation

Friend recommendation

Family recommendation

Advertising/publicity

Availability in my preferred format

Other

11. How often do you read for pleasure?

More than once a week (go to question 12) 
About once a week (go to question 12)

About once a fortnight (go to question 13)

About once every 3-4 weeks (go to question 13)

About once a month (go to question 13)

About once every 2-3 months (go to question 13)

Less often but read occasionally (go to question 13)

Never read (go to question 13)

12. You said you read at least once a week, could you say how many hours per week in total?

Less than 3 hours

Between 3 and 6 hours

Between 7 and 10 hours

More than 10 hours

13. Has the amount of time you spend reading for pleasure changed over the last 5 years?

It has increased (go to question 14)

It has decreased (go to question 15)

No change (go to question 16)

14. (If the amount of time you spend reading for pleasure has increased over the last 5 years), why is this?

Enjoy reading more now

Have more time available now

Prefer reading to some of the other things I used to do 
There are more formats available now

Reading materials are cheaper now

Reading materials are available to buy from more sources now

Other

15. (If the amount of time you spend reading for pleasure has decreased over the last 5 years), why is this?

Enjoy reading less now

Have less time available now

Prefer doing other things

There are fewer formats available now

Reading materials are more expensive now

Reading materials are available to buy from fewer sources now

Other

\section{Section 3: Reading for pleasure with others}

16. Do you belong to a book, reading or listening group?

Yes (go to question 17)

No (go to question 18)

17.What are the best things about belonging to this group?

Gives me confidence to speak in front of others

Opportunity to socialise

Chance to meet new people

Makes me feel part of a group/community

Helps me explore big issues/experiences/share ideas with others 
Supportive neutral setting

Chance to be creative

Allows me to escape to another world

The group is accessible to me

Introduces me to a wider range of books and authors

Provides an opportunity to talk about what l've read

Other

18. Is there anything else you would like to add about how reading for pleasure affects your life?

\section{Section 4: About you}

19. Where in the UK are you located?

England

Wales

Scotland

Northern Ireland

20. How old are you?

0-19

20-34

$35-49$

50-64

65-79

$80+$ 


\section{Gender}

Male

Female

22. Which of the following statements best describes what you are able to see?

(I will read a short list for you to choose from)

Prefer not to answer

No light perception

In a room during daytime, you can tell by the light where the windows are

You can see the shapes of the furniture in a room

You can see well enough to recognise a friend if you get close to his or her face

You can see well enough to recognise a friend who is at arm's length away

You can see well enough to recognise a friend across the room

You can see well enough to recognise a friend across the road

23. Have you had this sight condition since birth?

Yes

No

24. At what age did you lose, or start to lose your sight?

Pre-school (before the age of 5)

School age (between the ages of 5 and 18)

Adulthood (between the ages of 19 and 65)

Retirement (65 and over) 


\section{Authors}

Rachel Spacey, Claire Creaser and Debbie Hicks

Rachel Spacey,

(LISU), Loughborough University, UK

Claire Creaser

(LISU), Loughborough University, UK

Debbie Hicks

The Reading Agency, UK .

Corresponding author:

Rachel Spacey, LISU, Department of Information Science, Loughborough University, LE11 3TU, UK.

Email: r.e.spacey@lboro.ac.uk 